\title{
Supervisi Klinis sebagai upaya Peningkatan Kompetensi Pedagogik Guru dalam Kegiatan Belajar Mengajar Era Pandemik di SDN Kalibanteng Kulon 01 Semarang
}

\author{
Wiji Sri Wahyuningsih \\ SDN Kalibanteng Kulon 01 \\ wijisriwahyuningsih68@gmail.com
}

\begin{abstract}
Teachers of SDN Kalibanteng Kulon 01 Semarang city, at the beginning of the Covid-19 pandemic pedagogic competence in teaching and learning activities, teachers lacked technology mastery, the power of smartphones did not support downloading online learning support applications, quotas were wasteful, and signal was difficult, another thing is when teachers must create materials and assignments that are easily translated by parents and students. Online learning has many obstacles, especially communication, because the teaching pattern is only through short Whatsapp group messages or Google Classroom. In order to be successful in carrying out their duties, of course, teachers must have a set of abilities in the field to be delivered as well as the ability to convey material (material) so that it is easily accepted by their students, therefore teachers need to get clinical supervision from the principal so that there is an increase in pedagogic competence in teaching and learning activities. pandemic era. This study is intended to answer the problem of whether the implementation of clinical supervision can improve pedagogic competence in teaching and learning activities in the pandemic era at SDN Kalibanteng Kulon 01, Semarang city in 2020/2021?. These problems are discussed through school action research which is carried out through 2 cycles with each cycle the stages are planning, action, observation and reflection. The results show that the implementation of clinical supervision can improve pedagogic competence in teaching and learning activities in the pandemic era at SDN Kalibanteng Kulon 01 Semarang city in 2020/2021, this can be seen from the increase in the results of teacher professionalism in classroom administration management per cycle where in the first cycle there are 5 teachers. or $62.5 \%$ and in the second cycle there were 7 teachers or $87.5 \%$. These results indicate that these results are in line with expectations. The increase is the implementation of mini workshops to be one effective way for school principals in improving the ability of teachers in preparing learning tools
\end{abstract}

Keywords: Clinical Supervision, Improvement, Competence, Pedagogics, Teaching and Learning Activities, Pandemic Era.

Guru SDN Kalibanteng Kulon 01 kota Semarang, pada awal pandemi Covid-19 kompetensi pedagogik dalam kegiatan belajar mengajar, guru kurang menguasai teknologi, kekuatan smartphone yang kurang mendukung untuk mendownload aplikasi penunjang pembelajaran daring, borosnya kuota, dan susah sinyal, hal lain adalah ketika guru harus membuat materi dan tugas yang mudah diterjemahkan oleh orang tua maupun peserta didik. pembelajaran Daring banyak sekali hambatan khususnya komunikasi, karena pola pengajaran hanya melalui pesan singkat Whatsapp grup atau geogle clasrom. Agar sukses dalam menjalankan tugasnya tentunya guru harus memiliki seperangkat kemampuan dalam bidang yang akan disampaikan maupun kemampuan untuk menyampaikan bahan (materi) agar mudah diterima peserta didiknya, oleh karena itu guru perlu mendapatkan supervisi klinis dari kepala sekolah agar terjadi peningkatan ompetensi pedagogik dalam kegiatan belajar mengajar era pandemi. Studi ini dimaksudkan untuk menjawab permasalahan apakah pelaksanaan supervisi klinis dapat meningkatkan kompetensi pedagogik dalam kegiatan belajar mengajar era pandemik di SDN Kalibanteng Kulon 01 kota Semarang tahun 2020/2021?. Permasalahan tersebut di bahas melalui penelitian tindakan sekolah yang dilakukan melalui 2 siklus dengan setiap siklus tahapannya adalah perencanaan, tindakan, observasi dan refleksi. Hasil penelitian menunjukkan pelaksanaan supervisi klinis dapat meningkatkan kompetensi pedagogik dalam kegiatan belajar mengajar era pandemik di SDN Kalibanteng Kulon 01 kota Semarang tahun 2020/2021, hal ini dapat dilihat dari peningkatan hasil profesionalias guru dalam pengelolaan administrasi kelas per siklus dimana pada siklus I ada 5 guru atau $62,5 \%$ dan pada siklus II ada 7 
guru atau $87,5 \%$. Hasil tersebut menunjukkan bahwa hasil tersebut sesuai dengan yang diharapkan. Peningkatan tersebut pelaksanaan mini workshop menjadi salah satu cara yang efektif bagi kepala sekolah dalam meningkatkan kemampuan guru dalam menyusun perangkat pembelajaran

Kata Kunci: Supervisi Klinis, Peningkatan, Kompetensi, Pedagogik, Kegiatan Belajar Mengajar, Era Pandemik.

\section{PENDAHULUAN}

Pandemi Covid-19 mengharuskan masyarakat untuk melaksanakan pembelajaran secara daring pada semua elemen pendidikan. Guru merupakan elemen terpenting terhadap jalannya kegiatan belajar mengaja $r$, sehingga guru dituntut beradaptasi dengan cepat terhadap perubahan sistem pembelajaran. Guru perlu mengembangkan kompetensi dalam mengelola pembelajaran setelah adanya pandemi Covid-19. Pembelajaran daring sejatinya hampir sama dengan pembelajaran konvensional, yaitu suatu proses mentransfer ilmu, pembentukan spiritual, dan karakter melalui kegiatan yang dilakukan oleh guru dengan peserta didik dalam suasana lingkungan belajar. Perbedaannya hanya terletak pada sistem yang digunakan. Sistem pembelajaran konvensional dilakukan secara tatap muka langsung, sedangkan pembelajaran daring dilakukan secara tatap muka melalui suatu jaringan internet (Mahmudah, 2020).

Berdasarkan data awal guru SDN Kalibanteng Kulon 01 kota Semarang, pada awal pandemi Covid-19 kompetensi pedagogik dalam kegiatan belajar mengajar, guru kurang menguasai teknologi, kekuatan smartphone yang kurang mendukung untuk mendownload aplikasi penunjang pembelajaran daring, borosnya kuota, dan susah sinyal, hal lain adalah ketika guru harus membuat materi dan tugas yang mudah diterjemahkan oleh orang tua maupun peserta didik. pembelajaran Daring banyak sekali hambatan khususnya komunikasi, karena pola pengajaran hanya melalui pesan singkat Whatsapp grup atau geogle clasrom. Masih ditemukan beberapa guru yang mengajar tanpa acuan rencana pelaksanaan pembelajaran yang jelas. Hal ini dapat dimaklumi karena proses pelaksanaan pembelajaran secara daring (online) tentunya menyisakan banyak masalah dan kendala yang dialami baik oleh guru maupun peserta didik, begitu juga guru juga kurang mampu memanfaatkan secara maksimal WhatsApp (WA), telegram, instagram, aplikasi zoom ataupun media lainnya sebagai media pembelajaran yang dapat memahamkan siswa.

Jika supervisi dilaksanakan oleh kepala sekolah, maka ia harus mampu melakukan berbagai pengawasan dan pengendalian untuk meningkatkan kinerja tenaga kependidikan. Pengawasan dan pengendalian ini merupakan kontrol agar kegiatan pendidikan di sekolah terarah pada tujuan yang telah ditetapkan. Pengawasan dan pengendalian juga merupakan 
tindakan preventif untuk mencegah agar para tenaga kependidikan tidak melakukan penyimpangan dan lebih berhati-hati dalam melaksanakan pekerjaannya.

Berdasarkan latar belakang di atas peneliti tertarik untuk mengadakan penelitian tindakan sekolah tentang supervisi klinis sebagai upaya peningkatan kompetensi pedagogik dalam kegiatan belajar mengajar era pandemik di SDN Kalibanteng Kulon 01 Kota Semarang tahun 2020/2021

\section{KAJIAN TEORI}

Secara umum, istilah supervisi berarti mengamati, mengawasi atau membimbing dan menstimulir kegiatan-kegiatan orang lain dengan maksud untuk perbaikan (Soetopo dan Soemanto, 2014: 57). Richard Waller memberikan definisi tentang supervisi klinis sebagai berikut:

"Supervisi klinis adalah supervisi yang difokuskan pada perbaikan pengajaran dengan melalui siklus yang sistematis dari tahap perencanaan, pengamatan, dan analisis intelektual yang intensif terhadap penampilan mengajar sebenarnya dengan tujuan untuk mengadakan modifikasi yang rasional," (Clinical Supervision may be defined as supervision focused upon the improvement of instruction by means of systematic cycles of planning, observation and intensive intellectual analysis of actual teaching performances in the interest of rational modification).

Keith Acheson dan Meredith D. Gall, mengemukakan bahwa supervisi klinis adalah proses membantu guru memperkecil ketidak sesuai (kesenjangan) antara tingkah laku mengajar yang nyata dengan tingkah laku mengajar yang ideal.

Dari segi etimologi, paedagogik berasal dari bahasa Yunani yang artinya pendidikan. Paedagogik adalah kata majemuk yang terdiri dari kata paes yang berarti "anak" dan kata ago yang berarti "aku membimbing". Jadi paedagogik berarti aku membimbing anak (Ahmadi dan Uhbiyati, 2011: 70).

Secara epistimologi, paedagogik merupakan pemikiran bagaimana sebaiknya sistem pendidikan, tujuan pendidikan, materi pendidikan, sarana dan prasarana pendidikan, cara penilaian, cara penerimaan siswa, dan guru yang bagaimana (Ahmadi dan Uhbiyati, 2011: $68)$.

Jadi, kompetensi paedagogik dalam Kegiatan Belajar Mengajar Era Pandemi dalam merupakan suatu kompetensi yang dapat mencerminkan kemampuan mengajar seorang guru 
dimasa pandemi. Untuk dapat mengajar dengan baik maka yang bersangkutan harus menguasai teori dan praktek paedagogik dengan baik, dengan berbasis web.

Proses belajar mengajar merupakan inti dari pendidikan secara keseluruhan dengan guru sebagai pemegang peranan utama. Guru memiliki peran yang sangat penting dalam menentukan kuantitas dan kualitas pengajaran yang dilaksanakannya.

Kepala sekolah adalah seorang pemimpin sekolah yang juga berperan sebagai supervisor. Kerja supervisor adalah mengawasi dan mengendalikan atau mengontrol kegiatan pendidikan di sekolah terarah pada tujuan yang telah ditetapkan. Lebih jelasnya peneliti gambarkan dalam gambar berikut:

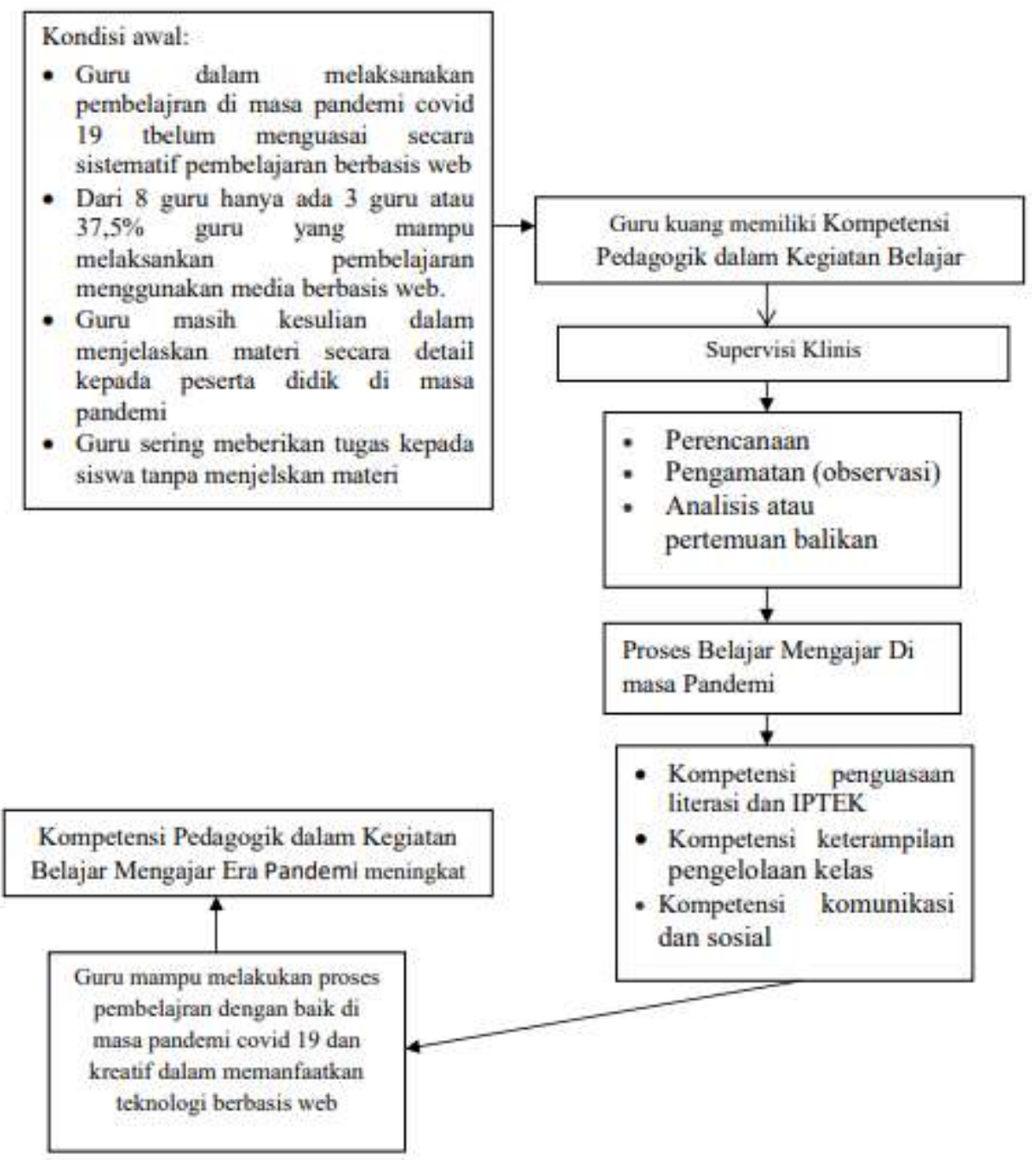

Gambar 1. Skema Kerangka Berpikir

Hipotesis tindakan dalam penelitian ini adalah terjadai pelaksanaan supervisi klinis dapat meningkatkan kompetensi pedagogik dalam kegiatan belajar mengajar era pandemik di SDN Kalibanteng Kulon 01 kota Semarang tahun 2020/2021. 


\section{METODE PENELITIAN}

Tempat penelitian SDN Kalibanteng Kulon 01 Kota Semarang. Penelitian ini dilakukan pada tanggal 20 januari 2021 sd 26 Maret 2021. Adapun subjek dalam penelitian ini adalah seluruh guru SDN Kalibanteng Kulon 01 Kota Semarang tahun 2020/2021 sejumlah 8 guru. Penelitian tindakan kelas ini dipilih dengan menggunakan model spiral dari Lewin penelitian adalah penelitian yang merupakan suatu rangkaian langkah-langkah ( $a$ Spiral of steps). Setiap langkah terdiri atas empat tahap, yaitu perencanaan, tindakan observasi, dan refleksi (Basrowi dan Suwandi, 2008: 27). Untuk lebih jelasnya rangkaian ini dapat di lihat pada gambar berikut:

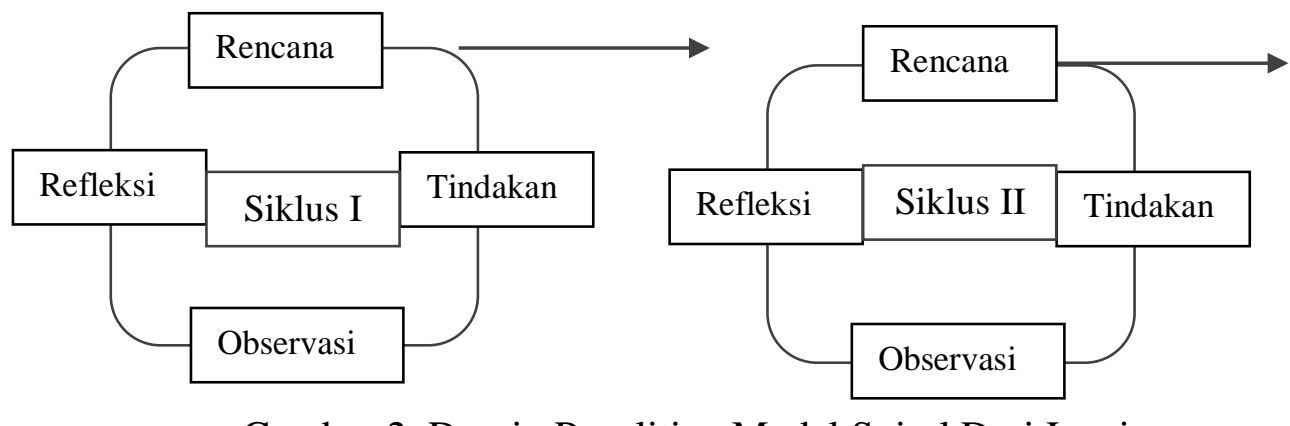

Gambar 2. Desain Penelitian Model Spiral Dari Lewin

\section{Teknik Pengumpulan Data}

1. Metode Observasi

Metode observasi merupakan suatu proses yang kompleks, suatu proses yang tersusun dari pelbagai proses biologis dan psikologis. Teknik pengumpulan data dengan observasi digunakan bila penelitian berkenaan dengan perilaku manusia, proses kerja, gejala-gejala alam dan bila responden yang diamati tidak terlalu besar (Sugiono, 2016: 203). Observasi dilakukan untuk mengamati kegiatan kegiatan belajar mengajar era pandemi yang dilakukan duru di SDN Kalibanteng Kulon 01 Kota Semarang tahun 2020/2021.

2. Metode Dokumentasi

Metode dokumentasi yaitu mencari data mengenai hal-hal atau variabel yang berupa catatan, buku, transkip, surat kabar majalah, prasasti, notulen rapat, legger, agenda dan sebagainya (Arikunto, 2012: 206). Metode ini digunakan untuk memperoleh data dokumen tentang perangkat pembelajaran yang ada pada guru.

\section{Alat Penilaian}


Alat penialain dalam penelitian ini adalah lebar observasi pengamatan terhadap kegiatan belajar mengajar yang di lakukan guru era pandemi di SDN Kalibanteng Kulon 01 Kota Semarang tahun 2020/2021 terlampir.

\section{Analisis Data}

Kemudian Data-data yang diperoleh dari penelitian baik melalui pengamatan, tes atau dengan menggunakan metode yang lain kemudian diolah dengan analisis deskriptif untuk menggambarkan keadaan peningkatan pencapaian indikator keberhasilan tiap siklus dan untuk menggambarkan keberhasilan pelasksnaan supervisi klinis dan peningkatan kompetensi pedagogik dalam kegiatan belajar mengajar era pandemi di SDN Kalibanteng Kulon 01 Kota Semarang tahun 2020/2021. Adapun tehnik pengumpulan data yang berbentuk kuantitatif berupa data-data yang disajikan berdasarkan angka-angka maka analisis yang digunakan yaitu prosentase dengan rumus sebagai berikut:

$$
\text { Nilai }=\frac{\text { Skor yang dicapai }}{\text { Jumlah Guru }} \times 100 \%
$$

Kriteria:

Baik Sekali (A) : $90<\mathrm{A} \leq 100$

Baik (B) $\quad: 70<\mathrm{B} \leq 89$

Cukup (C) $\quad: 60<\mathrm{C} \leq 79$

Kurang $(\mathrm{K}) \quad: \leq 60$

Sedangkan Untuk mengetahui tingkat keberhasilan penelitian tindakan sekolah ini apabila terjadi peningkatan kompetensi pedagogik dalam kegiatan belajar mengajar era pandemi di SDN Kalibanteng Kulon 01 Kota Semarang tahun 2020/2021 pada kategori baik dan baik sekali sebanyak $85 \%$.

\section{HASIL PENELITIAN}

Pelaksanaan siklus I dilakukan pada tanggal 20 Januari 2021

Tabel 1. Kompetensi Pedagogik dalam Kegiatan Belajar Mengajar Era Pandemi Semester Siklus I

\begin{tabular}{|c|c|c|c|}
\hline \multirow{2}{*}{ Kategori } & \multirow{2}{*}{ Angka } & \multicolumn{2}{|c|}{ Siklus I } \\
\cline { 3 - 4 } & & Guru & $\%$ \\
\hline Baik Sekali & $90 \%-100 \%$ & 3 & $37,5 \%$ \\
Baik & $70 \%-89 \%$ & 2 & $25 \%$ \\
\hline
\end{tabular}




\begin{tabular}{|l|c|c|c|} 
Cukup & $50 \%-69 \%$ & 3 & $37,5 \%$ \\
Kurang & $<49 \%$ & 0 & $0 \%$ \\
\hline \multicolumn{2}{|c|}{ Jumlah } & 8 & $100 \%$ \\
\hline \multicolumn{2}{|c|}{} \\
\hline
\end{tabular}

Dari tabel di atas dapat diketahui kompetensi pedagogik dalam kegiatan belajar mengajar era pandemi di SDN Kalibanteng Kulon 01 Kota Semarang tahun 2020/2021 pada siklus I dimana pada kategori baik sekali sebanyak 3 guru atau 37,5\%, kategori baik sebanyak 2 guru atau 25\%, kategori cukup sebanyak 3 guru atau 37,5\%, kategori kurang tidak guru atau $0 \%$.

\section{Siklus II}

Pelaksanaan siklus II dilakukan pada tanggal 19 Februari 2021. Berdasarkan hasil supervisi klinis ini peneliti menilai kegiatan belajar mengajar era pandemi yang telah dilakukan guru. Untuk lebih jelasnya diperoleh data yang digambarkan dalam tabel dan diagram berikut:

Tabel 2. Kompetensi Pedagogik dalam Kegiatan Belajar Mengajar Era Pandemi Siklus II

\begin{tabular}{|c|c|c|c|}
\hline \multirow{2}{*}{ Kategori } & \multirow{2}{*}{ Angka } & \multicolumn{2}{|c|}{ Siklus I } \\
\cline { 3 - 4 } & & guru & $\%$ \\
\hline Baik Sekali & $90 \%-100 \%$ & 4 & $50 \%$ \\
Baik & $70 \%-89 \%$ & 3 & $37,5 \%$ \\
\hline Cukup & $50 \%-69 \%$ & 1 & $12,5 \%$ \\
Kurang & $<49 \%$ & 0 & $0 \%$ \\
\hline \multicolumn{2}{|c|}{ Jumlah } & 8 & $100 \%$ \\
\hline
\end{tabular}

Dari tabel di atas dapat diketahui kompetensi pedagogik dalam kegiatan belajar mengajar era pandemi di SDN Kalibanteng Kulon 01 Kota Semarang tahun 2020/2021 pada siklus I dimana pada kategori baik sekali sebanyak 4 guru atau 50\% naik dari siklus I yaitu 3 guru atau 37,5, kategori baik sebanyak 3 guru atau 37,5\% naik dari siklus I yaitu 2 guru atau $25 \%$, kategori cukup sebanyak 1 guru atau 12,5\% turun dari siklus I yaitu 3 guru atau 37,5, kategori kurang sebanyak tidak ada guru atau 0\% sama dengan dari siklus I yaitu tidak ada guru atau $0 \%$. 
Dari tabel di atas menunjukkan kompetensi pedagogik dalam kegiatan belajar mengajar era pandemi di SDN Kalibanteng Kulon 01 Kota Semarang tahun 2020/2021 sudah baik.

\section{PEMBAHASAN}

Pelaksanaan supervisi klinis dalam kegiatan belajar mengajar era pandemi di SDN Kalibanteng Kulon 01 Kota Semarang tahun 2020/2021 pada pelaksanaan tindakan siklus I dan Siklus II dapat diketahui perubahan-perubahan peningkatan kompetensi pedagogik guru SDN Kalibanteng Kulon 01 Kota Semarang tahun 2020/2021 dalam kegiatan belajar mengajar era pandemi. Selengkapnya dapat dilihat pada tabel dan grafik sebagai berikut di bawah ini:

Tabel 3. Perbandingan Kategori Kompetensi Pedagogik dalam Kegiatan Belajar Mengajar Era Pandemi Siklus I dan Siklus II

\begin{tabular}{|c|c|c|c|c|c|}
\hline \multirow{2}{*}{ Kategori } & \multirow{2}{*}{ Nilai } & \multicolumn{2}{|c|}{ Siklus I } & \multicolumn{2}{c|}{ Siklus II } \\
\cline { 3 - 6 } & & Guru & $\%$ & Guru & $\%$ \\
\hline Baik Sekali & $90 \%-100 \%$ & 3 & $37,5 \%$ & 4 & $50,0 \%$ \\
\hline Baik & $70 \%-89 \%$ & 2 & $25,0 \%$ & 3 & $37,5 \%$ \\
\hline Cukup & $50 \%-69 \%$ & 3 & $37,5 \%$ & 1 & $12,5 \%$ \\
\hline Kurang & $<49 \%$ & 0 & $0 \%$ & 0 & $0 \%$ \\
\hline \multicolumn{2}{|c|}{ Jumlah } & 8 & $100 \%$ & 8 & $100 \%$ \\
\hline
\end{tabular}

Berdasarkan tabel dan grafik di atas menunjukkan kompetensi pedagogik dalam kegiatan belajar mengajar era pandemi pada siklus I ada 5 guru atau 62,5\% dan pada siklus II ada 7 guru atau $87,5 \%$, hasil tersebut sudah mencapai indikator yang ditentukan yaitu terjadi peningkatan kompetensi pedagogik dalam kegiatan belajar mengajar era pandemi di SDN Kalibanteng Kulon 01 Kota Semarang tahun 2020/2021 dengan pelaksanaan supervisi klinis pada siklus I, siklus II tiap individu yang mencapai $85 \%$ dari seluruh jumlah guru.

Hasil tabel dan grafik di atas di atas juga menunjukkan usaha yang dilakukan kepala sekolah dalam pelasksnaan supervisi mampu mampu meningkatkan kompetensi pedagogik dalam kegiatan belajar mengajar era pandemi di SDN Kalibanteng Kulon 01 Kota Semarang tahun 2020/2021. Hal ini bisa terjadi karena supervisi yang dilakukan oleh kepada sekolah menekankan pada keterbuakaan, hubungan yang harmonis, demokratisasi dan membimbing dengan sepenuh hati. 
Sebagaimana pendapat Usman (2012) saran utama supervisi klinis adalah para guru yang mempunyai peran sangat vital dalam membentuk karakter generasi penerus bangsa. Guru memiliki potensi untuk berkreasi dan meningkatkan kinerjanya.

Berdasarkan teori tersebut maka penelitian ini ada kesuaian antara data lapangan dan teori yang ada dan Hipotesis tindakan dalam penelitian ini yang menyatakan terjadai pelaksanaan supervisi klinis dapat meningkatkan kompetensi pedagogik dalam kegiatan belajar mengajar era pandemik di SDN Kalibanteng Kulon 01 kota Semarang tahun 2020/2021 terbukti dan diterima.

\section{SIMPULAN}

Dari hasil penelitian dan pembahasan dapat diambil kesimpulan bahwa pelaksanaan supervisi klinis dapat meningkatkan kompetensi pedagogik dalam kegiatan belajar mengajar era pandemik di SDN Kalibanteng Kulon 01 kota Semarang tahun 2020/2021

\section{SARAN}

Sehubungan dengan hasil penelitian yang peneliti lakukan, kiranya dapat memberikan saran sebagai berikut:

1. Bagi supervisor untuk dapat melakukan proses supervisi klinis yang mengedepankan humanisme pada guru dalam membimbing kinerja guru kegiatan belajar mengajar era pandemik

2. Bagi pihak guru hendakanya meningkatkan kualitas pembelajaran.

\section{DAFTAR PUSTAKA}

Abidah, A., dkk., 2020, The Impact of Covid-19 to Indonesian Education and Its Relation to the Philosophy of "Merdeka Belajar." Studies in Philosophy of Science and Education (SiPoSE), Vol. 1 No. 1

Ahmadi, Abu dan Nur Uhbiyati, 2011, Ilmu Pendidikan, Jakarta: Rineka Cipta

Arikunto, Suharsimi, 2012, Prosedur Penelitian Suatu Pendekatan Praktek, Jakarta: Rineka Cipta

Basrowi, Suwandi, 2008, Prosedur Penelitian Tindakan, Anggota IKAPI: Ghalia Indonesia

Batubara, H. H., \& Batubara, D. S. 2020, Penggunaan Video Tutorial Untuk Mendukung Pembelajaran Daring Di Masa Pandemi Virus Corona. Muallimuna: Jurnal Madrasah Ibtidaiyah, 5(2) 
Handayani, N. N. L., Dantes, N., \& Suastra, W. 2013. Pengaruh Model Pembelajaran Mandiri Terhadap Kemandirian Belajar dan Prestasi Belajar IPA Siswa Kelas VIII SMP N 3 Singaraja. Jurnal Pendidikan Dasar E-Journal Program Pascasarjana Universitas Pendidikan Ganeha, 3

Herliandry, L. D., dkk., 2020, Pembelajaran Pada Masa Pandemi Covid-19. Jurnal Teknologi Pendidikan, Volume 22 No. 1

Imania, K. A., \& Bariah, S. K. 2019, Rancangan Pengembangan Instrumen Penilaian Pembelajaran Berbasis Daring, Jurnal Petik, 5(1)

Kementerian Pendidikan dan Kebudayaan, 2006, Undang-Undang Republik Indonesia Nomor 14 Tahun 2005 Tentang Guru dan Dosen, Bab IV pasal 8, Bandung : Citra Umbara.

Komalasari, R. 2020, Manfaat Teknologi Informasi dan Komunikasi di Masa Pandemi Covid 19, TEMATIK - Jurnal Teknologi Informasi Dan Komunikasi, 7(1)

Kurniati, E., Nur Alfaeni, D. K., \& Andriani, F. 2020. Analisis Peran Orang Tua dalam Mendampingi Anak di Masa Pandemi Covid-19. Jurnal Obsesi : Jurnal Pendidikan Anak Usia Dini, 5(1), 241

Mahmudah, S. R. 2020, Pengaruh Pembelajaran Daring terhadap Psikologis Siswa

Margono, S., 2016, Metodologi Penelitian Pendidikan, Jakarta: Rineka Cipta

Mirabile, Richard J., 2007, Everything you Want to Know About Competency Modeling, http://www.umich.edu

Mulyasa, E., 2013, Menjadi Guru Profesional (Menciptakan Pembelajaran Kreatif dan Menyenangkan), Bandung: Remaja Rosdakarya

----------, 2014, Menjadi Kepala Sekolah Profesional, Bandung: Remaja Rosdakarya

Nasrullah, Rulli, 2015, Media Sosial: Perspektif Komunikasi, Budaya, dan Sosioteknologi, Bandung: Simbiosa Rekatama Media

Oke, A. and F. A. P. Fernandes, 2020, Innovations in Teaching and Learning: Exploring the Perceptions of the Education Sector on the 4th Industrial Revolution (4IR ), Journal of Open Innovation: Technology, Market, and Complexity, volume 6 No. 31,

Pidarta, Made, 2012, Pemikiran tentang Supervisi Pendidikan, Jakarta: Bumi Aksara

Pitasari, E. P., (eds), 2014, Panduan untuk Optimalisasi Media Sosial untuk Kementrian Perdagangan RI, Jakarta Pusat: Kementrian Perdagangan

Purwanto, M. Ngalim dan Sutadji Djojopranoto, Administrasi Pendidikan, Jakarta: Mutiara, 2014

----------, 2010, Administrasi dan Supervisi Pendidikan, (Bandung: Remaja Rosdakarya 
Ritonga, A.W., dkk., 2020, E-Learning Process of Maharah Qira'ah in Higher Education during the Covid-19 Pandemic. International Journal of Higher Education, volume 9

Rosmini, "Menciptakan Pembelajaran Kreatif dan Menyenangkan", http://www.sman2 mks. $\mathrm{com} /$ content/view/170/-64k.

Rusman dkk., 2011, Pembelajaran Berbasis Teknologi Informasi Dan Komunikasi: Mengembangkan Profesionalitas Guru, Jakarta: Raja Grafindo Persada

Sahertian, Piet A., 2012, Konsep Dasar dan Teknik Supervisi Pendidikan, (Jakarta : Rineka Cipta

Setiyani, R. (2010). Pemanfaatan Internet Sebagai Sumber Belajar. Dinamika Pendidikan, $5(2)$

Soetopo, Hendiyat dan Wasty Soemanto, 2014, Kepemimpinan dan Supervisi Pendidikan, Malang: Bina Aksara

Sugiono, 2016, Metodelogi Penelitian Pendidikan Pendekatan Kuantitatif, Kualitatif dan $R \& D$ (Bandung : Alfabeta

Suryani, N., 2016, Utilization of Digital Media to Improve The Quality and Attractiveness of The Teaching of History. Proceeding The $2^{\text {nd }}$ International Conference On Teacher Training and Education Sebelas Maret University, 2

Susanto, A. 2016. Manajemen Peningkatan Kinerja Guru Konsep Strategi dan Implementasinya, Cimanggis: Prenada Media Group.

Terdampak Social Distancing Akibat Covid 19, Jurnal Al-Mau'izhoh, 2(2)

Usman, Moh. Uzer, 2012, Menjadi Guru Profesional, (Bandung: PT. Remaja Rosdakarya

Wahyono, P., Husamah, H., \& Budi, A. S., 2020, Guru Profesional di Masa Pandemi COVID-19: Review Implementasi, Tantangan, dan Solusi Pembelajaran Daring, Jurnal Pendidikan Profesi Guru, 1(1)

Wardani, IGAK, 2016, Teori Belajar, Motivasi, dan Keterampilan Mengajar, Jakarta: Depdikbud

Wibowo, Mungin Eddy, "Sertifikasi Profesi Pendidik", http://www.suaramerdeka. com/harian/0602/06/opi04.htm,

Zarella, D., 2010, The Social Media Marketing Book, Canada: O’Reilly Media

http://sawali.wordpress,com/2007/07/15/latar_belakang_sertifikasi.

https://edukasi.sindonews.com 